\title{
FIRST AND NORTHERNMOST RECORD OF UPENEUS MOLUCCENSIS (ACTINOPTERYGII: PERCIFORMES: MULLIDAE) FROM THE SEA OF MARMARA
}

\author{
M. Levent ARTÜZ ${ }^{1 *}$ and Ronald FRICKE ${ }^{2}$ \\ ${ }^{1}$ Sevinç-Erdal İnönü Foundation, Marmara Environmental Monitoring Project (MAREM), Department of Marine \\ Sciences, Istanbul, Turkey \\ ${ }^{2}$ Lauda-Königshofen, Germany
}

Artüz M.L., Fricke R. 2019. First and northernmost record of Upeneus moluccensis (Actinopterygii: Perciformes: Mullidae) from the Sea of Marmara. Acta Ichthyol. Piscat. 49 (1): 53-58.

\begin{abstract}
The goldband goatfish, Upeneus moluccensis (Bleeker, 1855), is an Indo-West Pacific species, which has been reported as a Lessepsian migrant from the eastern Mediterranean Sea. The species has expanded its distribution range in the Mediterranean; individuals have been recorded from Israel, Lebanon, Libya, the south coast of Turkey, and the Aegean Sea. The aim of this study was to report the presence of U. moluccensis in the Sea of Marmara. The history of the Mediterranean records and the presence in the Sea of Marmara are discussed. A specimen of Upeneus moluccensis was collected with a beam trawl at $58 \mathrm{~m}$ depth, off Aksaz, the western Sea of Marmara during the MAREM (Marmara Environmental Monitoring) survey, on 21 June 2017. The fish (a female) was subjected to standard descriptive procedures and subsequently deposited in the collection of the MAREM (Marmara Environmental Monitoring) project, with the catalogue number LAR-182. Upeneus moluccensis is recorded for the first time from the Sea of Marmara, which expands its distributional range westward in the Mediterranean Sea (Aegean Sea). This new distribution record of Upeneus moluccensis also represents the global northernmost record of the species. The previous northernmost record was from $38^{\circ} 53^{\prime} \mathrm{N}$ in the northern Aegean Sea, and from about $35^{\circ} 12^{\prime} \mathrm{N}$ in its natural range (southern Japan).
\end{abstract}

Keywords: Mullidae, goldband goatfish, morphometry, expanded distribution

\section{INTRODUCTION}

The family Mullidae includes six valid genera (Fricke et al. 2018), five of which are present in the north-eastern Atlantic and the Mediterranean, Mulloidichthys, Mullus, Parupeneus, Pseudupeneus, and Upeneus, comprising one, two, one, one, and two species, respectively; the genera Parupeneus and Upeneus are only represented by Lessepsian migrants. The genera Upeneus includes a total of 39 valid species, with 10 species known from the Red Sea (Golani and Fricke 2018). Only Upeneus moluccensis (Bleeker, 1855) and Upeneus pori Ben-Tuvia et Golani, 1989 have been reported as Lessepsian migrants in the eastern Mediterranean Sea.

The goldband goatfish, Upeneus moluccensis, was originally described by Bleeker (1855: 409, Upeneoides moluccensis) from Ambon (Maluku, Indonesia). The native distribution range of this species extends from the Red Sea, East Africa, Madagascar and Réunion east to the Caroline Islands and New Guinea, north to southern Japan, south to Western Australia and Queensland (Australia) (Fricke et al. 2018). The western Indian Ocean populations were reviewed and compared with other species by Uiblein and Heemstra (2010).
Upeneus moluccensis was first reported from the Mediterranean coast of Israel by Haas and Steinitz (1947) and Ben-Tuvia (1953), misidentified as "Mulloides auriflamma (non Forsskål, 1775)". Since that time, U. moluccensis has become a commercially important demersal species, living in shoals in sandy-muddy or muddy habitats at depths between 20 and $130 \mathrm{~m}$. It is very abundant in the eastern Levantine Sea (Golani et al. 2002), and is heavily fished (Erguden et al. 2010).

Upeneus moluccensis extends in the Mediterranean Sea from the coast of Israel, Lebanon, Libya, southern coasts of Turkey and to Aegean Sea (Hureau 1986, Golani et al. 2002, Aydın and Akyol 2016). Tikochinski et al. (2013) demonstrated that no significant genetic differences exist between populations of U. moluccensis from the Mediterranean Sea, Red Sea, and Japan. Before the presently reported occurrence the northernmost report was from the Gulf of Çandarl, Aegean Sea (Aydın and Akyol 2016).

The Sea of Marmara is an inland sea within Turkey with a maximum depth of $1272 \mathrm{~m}$.

Due, in large part, to the structural characteristics of the Turkish Straits (the Çanakkale Strait or Dardanelles, and

" Correspondence: M. Levent Artüz, Sevinç-Erdal İnönü Vakfı, MAREM (Marmara Environmental Monitoring) Proje Lideri, Deniz araştırmaları bölümü, Anadoluhisarı Toplarönü No: 8, 34810, Istanbul, Turkey, phone+90 532-415-7285, e-mail: (MLA) levent@artuz.com, (RF) ronfricke@web.de. 
the Boğaziçi or Bosporus), the Sea of Marmara has unique hydrodynamic features and connects the Mediterranean Sea with the Black Sea.

The Sea of Marmara and the Straits provide an important "acclimatization zone" for transiting species of fishes during their migration from the Black Sea to the Mediterranean Sea and vice versa and works like a biological corridor between those very different seas.

The Sea of Marmara has, in vertical section, two water masses which are distinctly separated from each other by a thermo-halocline interface. The surface water mass consists of low salinity Black Sea water, with a salinity of $19 \%{ }^{-}-26 \%{ }^{*}$ according to the season and inflow from the Black Sea, and a temperature varying between 5 and $29^{\circ} \mathrm{C}$ depending the atmospheric conditions (Okay et al. 2007), extending to an average depth of about $25-30 \mathrm{~m}$.

The lower water mass is originating from the high salinity Aegean and Mediterranean waters which has a constant temperature of $14.2^{\circ} \mathrm{C}$, a salinity of $38.5 \%$ and no seasonal variations (Okay et al. 2007), occupying all depths below 25-30 $\mathrm{m}$ in the Sea of Marmara.

\section{MATERIALS AND METHODS}

A single female specimen of Upeneus moluccensis was collected with a beam trawl at $58 \mathrm{~m}$ depth, off Aksaz, the western Sea of Marmara (Fig. 1) during the MAREM (Marmara Environmental Monitoring) Survey, on 21 June 2017.

The fish, subjected to standard descriptive procedures (Hubbs and Lagler 1947, Uiblein and Heemstra 2010), were identified, measured with a digital calliper, photographed, and dissected for sex determination. It was later fixed in $10 \%$ formalin buffered with seawater and subsequently deposited in the collection of the Marmara Environmental Monitoring project (MAREM), with the code of LAR-182. Fin-ray counts follow Fricke (1983). The family classification follows van der Laan et al. (2014), genus and species classification follows Fricke et al. (2018).

\section{RESULTS}

Family Mullidae Rafinesque, 1815

Upeneus Cuvier, 1829

Upeneus moluccensis (Bleeker, 1855)

Fig. 2, Table 1.

Material. MAREM LAR-182, one female, 108.5 $\mathrm{mm}$ SL, off Aksaz, western Sea of Marmara, Turkey, $40^{\circ} 25.100^{\prime} \mathrm{N}, 26^{\circ} 59.700^{\prime} \mathrm{E}-40^{\circ} 24.600^{\prime} \mathrm{N}, 26^{\circ} 59.350^{\prime} \mathrm{E}, 58$ $\mathrm{m}$ depth, Cruise MAREM, beam trawl, St. ALG-7, 21 June 2017.

Description. Body moderately elongated, deepest at beginning of first dorsal fin; mouth terminal, snout rounded, pair of small barbels attached to tip of ceratohyal, behind symphysis of lower jaw not reaching posterior part of operculum margin; maxilla slightly exceeding anterior border of eye. Villiform teeth on jaws, vomer and palatine. First spine of first dorsal fin shorter than 2 nd. Total lateral line scales 33, with 22 pored scales. Dorsal and anal fins basally with scaled area. Counts, morphometric measurements, and proportions given in Table 1.

Colour in dorsal part of body with golden yellow longitudinal band as wide as pupil, extending from eye to caudal-fin base; head and body silvery reddish above strip, silvery white below, posteriorly with rosy shade; barbels whitish; 3 orange stripes on first dorsal fin, 2 on second; 6 thin red bars on upper caudal-fin lobe, lower lobe of caudal fin with a broad rose longitudinal stripe.

Distribution. Red Sea, Indo-West Pacific: East Africa, Madagascar and Réunion east to Caroline Islands and New Guinea, north to southern Japan, south to Western Australia and Queensland (Australia). Absent from the Persian Gulf, where the species is replaced by the similar species Upeneus doriae (Günther, 1869). Lessepsian migrant in the eastern Mediterranean, where the species was recorded from Egypt, Libya, Gaza, Israel, Lebanon, Syria, Cyprus, Turkey, and Greece.

Habitat. Benthic, on sandy or muddy bottoms from shallow water to depths of $100 \mathrm{~m}$ (a single record from $200 \mathrm{~m}$ depth) (Golani et al. 2002).

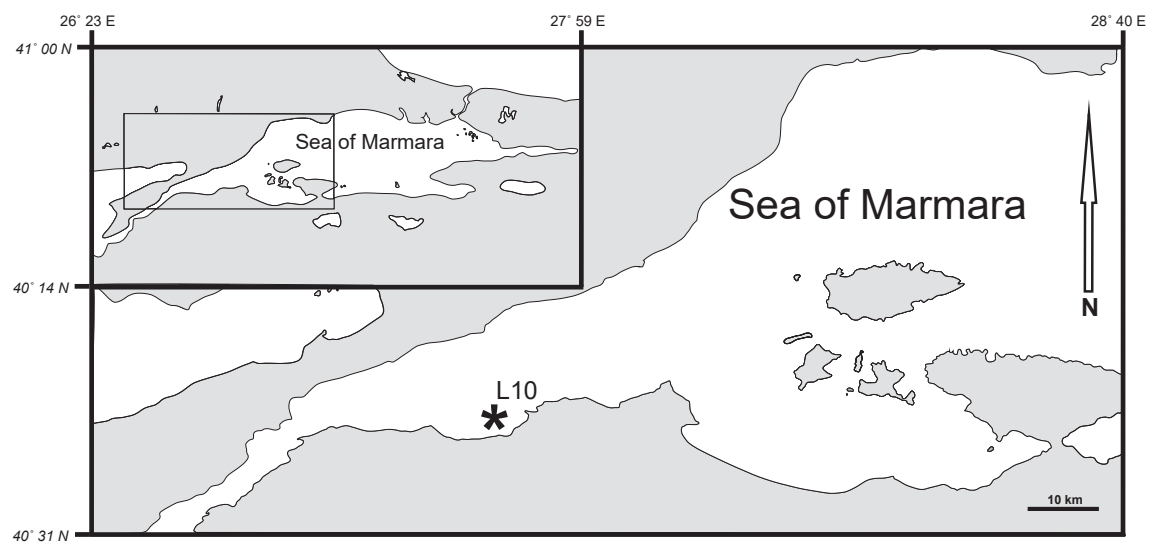

Fig. 1. Map indicating the collecting locality of the specimen of Upeneus moluccensis, MAREM LAR-182, in the Sea of Marmara, Turkey 


\section{Table 1 DISCUSSION}

Morphometric measurements, meristic values, and proportions of the specimen of Upeneus moluccensis from the Sea of Marmara (MAREM LAR-182; female, $28.1 \mathrm{~g}$ )

\begin{tabular}{|c|c|c|c|}
\hline \multirow[b]{2}{*}{ Parameter } & \multicolumn{2}{|c|}{ Morphometric values } & \multirow[b]{2}{*}{$\begin{array}{c}\text { Meristic } \\
\text { values }\end{array}$} \\
\hline & $\begin{array}{c}\text { Absolute } \\
\text { value } \\
{[\mathrm{mm}]}\end{array}$ & $\begin{array}{c}\text { Relative } \\
\text { value }[\%]\end{array}$ & \\
\hline Total length (TL) & 128.9 & & \\
\hline Standard length (SL) & 108.5 & $84.2 \mathrm{TL}$ & \\
\hline Caudal-fin length & 21.3 & $19.6 \mathrm{SL}$ & \\
\hline Head length (HL) & 30.3 & $27.9 \mathrm{SL}$ & \\
\hline Head width & 14.7 & $13.5 \mathrm{SL}$ & \\
\hline Head depth & 18.6 & 17.1 SL & \\
\hline Body depth & 28.4 & $26.2 \mathrm{SL}$ & \\
\hline Body width & 17.0 & $15.7 \mathrm{SL}$ & \\
\hline Caudal-peduncle length & 27.1 & $25.0 \mathrm{SL}$ & \\
\hline Caudal-peduncle depth & 19.3 & $17.8 \mathrm{SL}$ & \\
\hline Orbit diameter & 10.1 & $33.3 \mathrm{HL}$ & \\
\hline Interorbital distance & 18.3 & $60.4 \mathrm{HL}$ & \\
\hline Upper jaw length & 16.6 & $54.8 \mathrm{HL}$ & \\
\hline Lower jaw length & 15.5 & $51.2 \mathrm{HL}$ & \\
\hline Snout length & 10.8 & $35.6 \mathrm{HL}$ & \\
\hline Postorbital length & 12.4 & $40.9 \mathrm{HL}$ & \\
\hline Barbel length & 17.8 & $16.4 \mathrm{SL}$ & \\
\hline Predorsal (1) length & 37.2 & $34.3 \mathrm{SL}$ & \\
\hline Predorsal (2) length & 68.5 & $63.1 \mathrm{SL}$ & \\
\hline Prepectoral length & 33.4 & $30.8 \mathrm{SL}$ & \\
\hline Preanal length & 68.6 & $63.2 \mathrm{SL}$ & \\
\hline Prepelvic length & 33.3 & $30.7 \mathrm{SL}$ & \\
\hline Length of 1 st D1 spine & 18.8 & $17.3 \mathrm{SL}$ & \\
\hline Length of 2nd D1 spine & 20.6 & 19.0 SL & \\
\hline Length of 3rd D1 spine & 20.2 & $18.6 \mathrm{SL}$ & \\
\hline Length of D2 & 13.9 & $12.8 \mathrm{SL}$ & \\
\hline $\begin{array}{l}\text { Length of 1st anal-fin } \\
\text { spine }\end{array}$ & 15.0 & $13.8 \mathrm{SL}$ & \\
\hline Length of pelvic-fin spine & 18.2 & $16.8 \mathrm{SL}$ & \\
\hline Pectoral fin length & 22.0 & $20.3 \mathrm{SL}$ & \\
\hline Pelvic fin length & 18.2 & $16.8 \mathrm{SL}$ & \\
\hline Length of D1 base & 14.7 & $13.5 \mathrm{SL}$ & \\
\hline Length of D2 base & 8.1 & $7.5 \mathrm{SL}$ & \\
\hline Length of anal-fin base & 11.0 & $10.1 \mathrm{SL}$ & \\
\hline $\begin{array}{l}\text { No of lateral line } \\
\text { (LL) scales }\end{array}$ & & & 33 \\
\hline $\begin{array}{l}\text { No of transverse scales } \\
\text { above LL }\end{array}$ & & & 3 \\
\hline $\begin{array}{l}\text { No of transverse scales } \\
\text { below LL }\end{array}$ & & & 4 \\
\hline Gill rakers & & & $9+18$ \\
\hline 1st Dorsal fin & & & VIII \\
\hline 2nd Dorsal fin & & & 9 \\
\hline
\end{tabular}

The meristic, morphometric, and colouration characters of the specimen from the Sea of Marmara are in accordance with the descriptions of Upeneus moluccensis by Hureau (1986), Golani et al. (2002), and Uiblein and Heemstra (2010). Golani and Ritte (1999) compared Mediterranean and Red Sea populations of U. moluccensis genetically but found no discernible genetic distance between those populations.

The geographical distribution of the species in the eastern Mediterranean Sea was reviewed by Ben-Tuvia (1966). The first records from different countries/regions in the Mediterranean Sea are compared in Table 2. Though the Suez Canal was opened in 1869, Upeneus moluccensis was first recorded from the Canal by Gruvel (1936). That late discovery may have been due to a lack of scientific research in the area in the decades before, but may also have been real, as the Suez Canal was dug through salt lakes, which were initially very salty. The salt was gradually washed out in the following 50 or 60 years, which only then allowed the passage of some fish species. According to Ben Rais Lasram et al. (2008), U. moluccensis had a strong initial dispersal success and had established reproducing populations in Rhodes (Greece) as early as 1948, when the species was reported as a common off the island by Laskaridis (1948). The subsequent westward dispersal was considerably slower; U. moluccensis has not yet been observed in Tunisia. The northward dispersal also slowed down considerably; only in 2000 the species was reported from the southern Aegean Sea (Torcu and Mater 2000), in 2016 from the northern Aegean Sea (Aydin and Akyol 2016), and in 2017 from the Sea of Marmara (presently reported study). If $U$. moluccensis should establish reproducing populations in the Sea of Marmara, it is possible that it even might further expand its distribution range to the southern Black Sea in the future. So far, just a single species of a Lessepsian migrant fish is known to have entered the Black Sea, i.e., the carangid fish Alepes djedaba (Forsskål, 1775), as reported by Turan et al. (2017), which was recorded three years before from the Sea of Marmara (Artüz and Kubanç 2014).

This is a new global northernmost record of the species, from $40^{\circ} 25^{\prime} \mathrm{N}$. The previous northernmost record was from $38^{\circ} 53^{\prime} \mathrm{N}$ in the northern Aegean Sea (Aydın and Akyol 2016). In its natural distribution range, the IndoWest Pacific, the northernmost record is from $29^{\circ} 32^{\prime} \mathrm{N}$ in the northern Gulf of Aqaba, Israel (Fowler and Steinitz 1956). The species was not yet recorded from the Gulf of Suez (Golani and Fricke 2018), although it evidently occurs there. In the eastern part of its distribution range, the species occurs north to about $35^{\circ} 12^{\prime} \mathrm{N}$ (southern Japan).

The Red Sea immigrants entered the Mediterranean from the Suez Canal began to move out continuously towards the north, mainly depending on the water temperature (Boudouresque 1999). In recent years a few of these were encountered in the Sea of Marmara, now including a total of six species (Artüz and Golani 2018) (seven with the presently reported finding). 


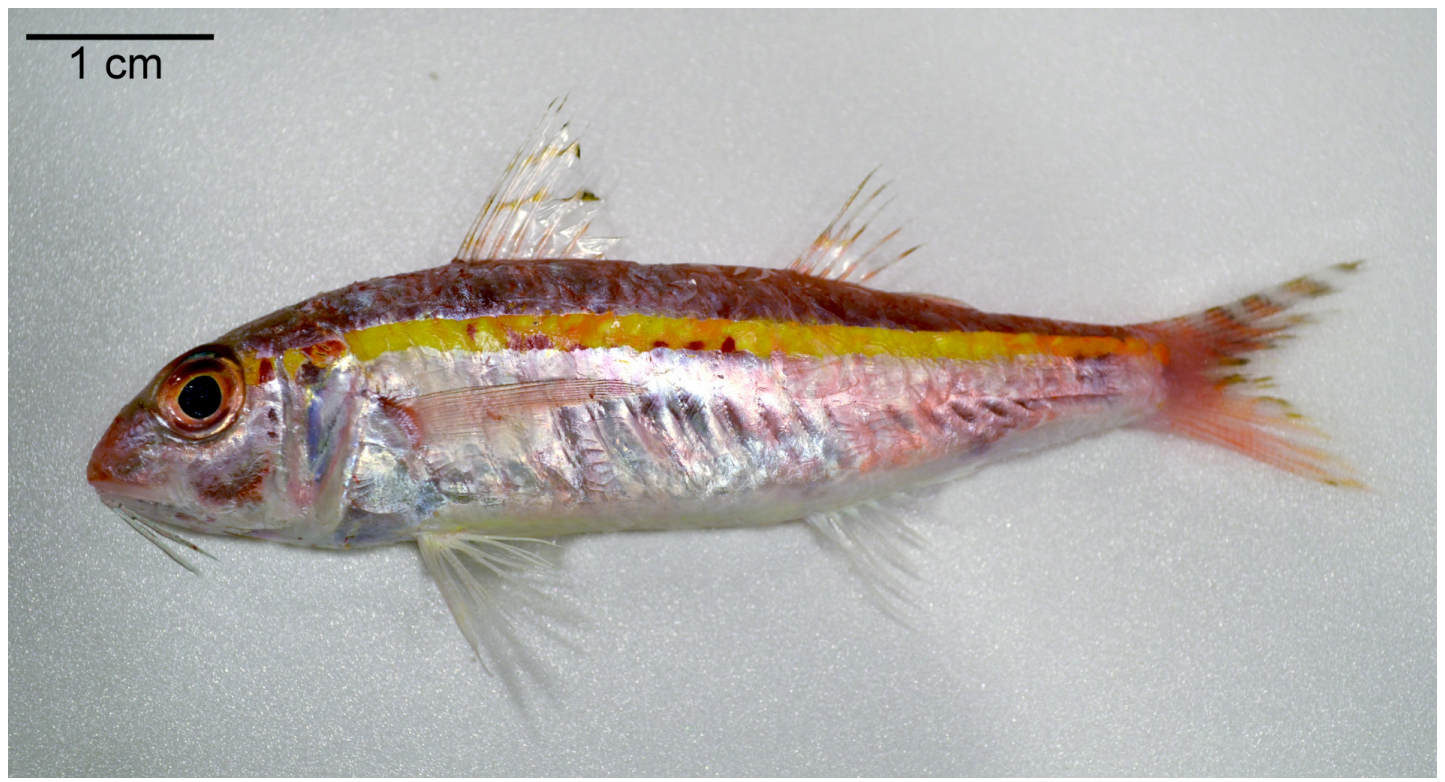

Fig. 2. Female specimen of Upeneus moluccensis, MAREM LAR-182, 108.5 mm SL, off Aksaz, western Sea of Marmara, Turkey

Distribution of Lessepsian migrant populations

Table 2

of Upeneus moluccensis in the Mediterranean Sea: first (and second) country (region) records

\begin{tabular}{ll}
\hline \multicolumn{1}{c}{ Country (region) } & \multicolumn{1}{c}{ Record } \\
\hline Egypt (Suez Canal) & Gruvel 1936, as Mulloides flavolineatus \\
& Ben-Tuvia 1955 \\
Egypt (Mediterranean coast) & Ben-Tuvia 1955 \\
Gaza & Ben-Tuvia 1955 \\
Israel & Haas and Steinitz 1947, as Mulloides auriflamma \\
& Ben-Tuvia 1955 \\
Lebanon & George et al. 1964 \\
Syria & Saad 1998 \\
Cyprus & Demetropoulos and Neocleous 1969 \\
Greece (Rhodes) & Laskaridis 1948, as Mulloides auriflamma \\
& Ben-Tuvia 1955 \\
Turkey (Mediterranean Sea coast) & Kosswig 1950 \\
Turkey (southern Aegean Sea) & Torcu and Mater 2000 \\
Turkey (northern Aegean Sea) & Aydin and Akyol 2016 \\
Turkey (Sea of Marmara) & Presently reported study \\
\hline
\end{tabular}

Regarding the database of the General Directorate of Meteorology between 1970 and 2017 the mean water temperature in the Sea of Marmara was $15^{\circ} \mathrm{C}$ in the $1970 \mathrm{~s}$, subsequently steadily increasing to $16.2^{\circ} \mathrm{C}$ in the less saline $(\approx 22 \%$ o- $26 \%$ o $)$ and dense $\left(\approx \sigma_{\mathrm{t}} 11-17\right)$ surface water mass (Anonymous 2018). On the contrary, the saline $(\approx$ $36 \%$ - $38 \%$ o $)$ and dense $\left(\approx \sigma_{t} 26-29\right)$ lower water mass did not increase and still has a constant temperature of $14.2^{\circ} \mathrm{C}$ (Artüz et al. 2018).

The special hydrographical features of the Sea of Marmara and reduction of species diversity create a suitable environment for invasive and new species due to anthropogenic activities (pollution, overfishing, dense maritime traffic, etc.).

\section{ACKNOWLEDGEMENTS}

The benthic survey was part of the MAREM (Marmara Environmental Monitoring) project. The main project has been funded by the Sevinç-Erdal İnönü Foundation, Turkey. We gratefully acknowledge the crew of the vessel Oktay 4 for their help in collecting the material and to the Kartal Municipality and the mayor Altınok Örs, for partial financial support to the main project.

\section{REFERENCES}

Anonymous 2018. Meteoroloji Genel Müdürlüğü. [Turkish State Meteorological Service.] [Accessed on 27 July 2018.] http://www.mgm.gov.tr/index.aspx\#sfU 
Artüz M.L., Artüz O.B., Gülen D., Sakınç M., Yalçın B., Tunçer S., Yılmaz N. 2018. Marmara Denizi'nin Değişen Oşinografik Şartlarının İzlenmesi Projesi (MAREM) 2017 Senesi Çalışma Verileri. [Monitoring of the changing oceanographic conditions of the Sea of Marmara (MAREM), data of the year 2017.] Türkiye Barolar Birliği. Ankara, Turkey. [In Turkish.]

Artüz M.L., Golani D. 2018. First and most northern record of Sargocentron rubrum (Forsskål, 1775) from the Sea of Marmara. Thalassas: An International Journal of Marine Sciences 34 (2): 377-381. DOI: 10.1007/s41208-018-0075-0

Artüz M.L., Kubanç N. 2014. First record of shrimp scad Alepes djedaba (Carangidae) from the Sea of Marmara, Turkey. Cybium 38 (4): 319-320.

Aydın I., Akyol O. 2016. Northernmost record of Upeneus moluccensis (Bleeker, 1855) (Osteichthyes: Mullidae) in the Turkish coasts of the Aegean Sea. Turkish Journal of Fisheries and Aquatic Sciences 16 (3): 749752. DOI: $10.4194 / 1303-2712-v 16 \_3$ 30

Ben Rais Lasram F., Tomasini J.A., Guilhaumon F., Romdhane M.S., Chi T.D., Mouillot D. 2008. Ecological correlates of dispersal success of Lessepsian fishes. Marine Ecology Progress Series 363: 273-286. DOI: $10.3354 /$ meps 07474

Ben-Tuvia A. 1953. Mediterranean fishes of Israel. The Sea Fishes Research Station, Haifa, Bulletin 8: 1-40.

Ben-Tuvia A. 1955. Two Indo-Pacific fishes, Dasyatis uarnak and Upeneus moluccensis, in the eastern Mediterranean. Nature 176 (4494): 1177-1178. DOI: $10.1038 / 1761177 \mathrm{~b} 0$

Ben-Tuvia A. 1966. Red Sea fishes recently found in the Mediterranean. Copeia 1966 (2): 254-275. DOI: $10.2307 / 1441133$

Bleeker P. 1855. Zesde bijdrage tot de kennis der ichthyologische fauna van Amboina. [The sixth contribution to the knowledge of the ichthyological fauna of Amboina.] Natuurkundig Tijdschrift voor Nederlandsch Indië 8 (3): 391-434. [In Dutch.]

Boudouresque C.F. 1999. [Chapter 14] The Red SeaMediterranean link: Unwanted effects of canals. Pp. 213-228. In: Sandlund O.T., Schei P.J., Viken Å. (eds.) Invasive species and biodiversity management. Population and Community Biology Series 24. Kluwer Academic Publishers, Dordrecht, the Netherlands.

Demetropoulos A., Neocleous D. 1969. The fishes and crustaceans of Cyprus. Fisheries Bulletin, Ministry of Agriculture and Natural Resources, Department of Fisheries, Cyprus 1: 3-21.

Erguden D., Turan C., Gurlek M. 2009. Weight-length relationships for 20 Lessepsian fish species caught by bottom trawl on the coast of Iskenderun Bay (NE Mediterranean Sea, Turkey). Journal of Applied Ichthyology 25 (1): 133-135. DOI: 10.1111/j.14390426.2008.01198.x

Fricke R. 1983. A method for counting caudal fin ray of actinopterygian fishes. Braunschweiger Naturkundliche Schriften 1 (4): 729-733.
Fricke R., Eschmeyer W.N., van der Laan R. (eds.) 2018. Catalog of fishes: Genera, species, references. California Academy of Sciences, San Francisco, USA. [Accessed on 16 December 2018.] http://researcharchive.calacademy.org/research/ ichthyology/catalog/fishcatmain.asp

George C.J., Athanassiou V.A., Boulos I. 1964. The fishes of the coastal waters of Lebanon. The American University of Beirut, Faculty of Arts and Sciences; Miscellaneous Papers in the Natural Sciences 4: 1-27.

Golani D., Fricke R. 2018. Checklist of the Red Sea fishes with delineation of the Gulf of Suez, Gulf of Aqaba, endemism and Lessepsian migrants. Zootaxa 4509 (1): 1-215. DOI: 10.11646/zootaxa.4509.1.1

Golani D., Orsi-Relini L., Massutí E., Quignard J.-P. 2002. CIESM atlas of exotic species in the Mediterranean. Vol. 1, Fishes. CIESM Publishers, Monaco.

Golani D., Ritte U. 1999. Genetic relationship in goatfishes (Mullidae: Perciformes) of the Red Sea and the Mediterranean, with remarks on Suez Canal migrants. Scientia Marina 63 (2): 129-135. DOI: 10.3989/scimar.1999.63n2129

Gruvel A. 1936. Contribution a l'étude de la bionomie générale et de l'exploration de la faune du canal de Suez. Mémoires présentées à l'Institut d'Égypte 29: 1-255.

Haas G., Steinitz H. 1947. Eritrean fishes on the Mediterranean coast of Palestine. Nature 160 (4053): 28. DOI: $10.1038 / 160028 b 0$

Hubbs C.L., Lagler K.F. 1947. Fishes of the Great Lakes Region. Bulletin of the Cranbrook Institute of Science 26: i-vi + 1-186.

Hureau J.-C. 1986. Mullidae. Pp. 877-882. In: Whitehead P.J.P., Bauchot M.-L., Hureau J.-C., Nielsen J., Tortonese E. (eds.) Fishes of the north-eastern Atlantic and the Mediterranean. Vol. 2. UNESCO, Paris.

Kosswig C. 1950. Erythräische Fische im Mittelmeer und an der Grenze der Ägäis. Pp. 203-212. In: von Jordans A., Peus F. (eds.) Syllegomena Biologica. Festschrift zum 80. Geburtstag von Herrn Pastor Dr. med. h. c. Otto Kleinschmidt, Lutherstadt Wittenberg am 13. Dezember 1950. Akademische Verlagsgesellschaft Geest und Portig / A. Ziemsen Verlag, Leipzig/ Wittenberg, Germany.

Laskaridis K. 1948. Symvolí eis tin melétin tis viologías tou ichthýos Mulloides auriflamma (Forsk). [Contribution to the study of the biology of the fish Mulloides auriflamma (Forsk.).] Anátypon praktiká tou ellinikoú ydroviologikoú instistoútou tis Akadimías Athinón. [Proceedings of the Hellenic Hydrobiological Institute of the Academy of Athens.] 2 (1): 103-118. [In Greek.]

Okay I.A., Mater B., Artüz O.B., Gürseler G., Artüz M.L., Okay N. 2007. Bilimsel Açıdan Marmara Denizi. [Scientific aspects of the Sea of Marmara.] Türkiye Barolar Birliği Yayınları, Ankara, Turkey. [In Turkish.]

Saad A. 1998. Reproductive cycle and fecundity of Upeneus moluccensis (Bleeker, 185), Indo-Pacific species, in Syrian sea waters (eastern Mediterranean Sea). Cahiers Options Méditerranéennes 35: 87-92. 
Tikochinski Y., Friling M., Harush N., Lizarovich R., Manor N., Horsky A., Appelbaum-Golani B., Golani D. 2013. Molecular comparison of geographically extreme populations of fish species of wide Indo-Pacific distribution. Israel Journal of Ecology and Evolution 59 (4): 197-200. DOI: 10.1080/15659801.2013.908600

Torcu H., Mater S. 2000. Lessepsian fishes spreading along the coasts of the Mediterranean and the southern Aegean Sea of Turkey. Turkish Journal of Zoology 24 (2): 139-148.

Turan C., Gürlek M., Özeren A., Doğdu S.A. 2017. First Indo-Pacific fish species from the Black sea of
Turkey: Shrimp scad Alepes djedaba (Forsskål, 1775) (Carangidae). Natural and Engineering Sciences 2 (3): 149-157. DOI: 10.28978/nesciences.358911

Uiblein F., Heemstra P.C. 2010. A taxonomic review of the western Indian Ocean goatfishes of the genus Upeneus (Family Mullidae), with descriptions of four new species. Smithiana, Publications in Aquatic Biodiversity, Bulletin 11: 35-71.

van der Laan R., Eschmeyer W.N., Fricke R. 2014. Family-group names of recent fishes. Zootaxa $\mathbf{3 8 8 3}$ (2): 1-230. DOI: 10.11646/zootaxa.3882.1.1

Received: 30 July 2018 Accepted: 4 September 2018 Published electronically: 15 March 2019 